\title{
Yield response of watermelon, tomato and pigeon pea to land preparation techniques in southern Puerto Rico'
}

\author{
Héctor M. Lago-Mercado', José Badillo-Feliciano ${ }^{2}$ \\ and Francisco H. Ortiz-Alvarado ${ }^{3}$
}

\begin{abstract}
Two field experiments were conducted in a Mollisol of the southern region of Puerto Rico to evaluate the effect of three different tillage techniques versus no tillage on the yield of watermelon, tomato and pigeon pea. No-till (undisturbed), minimum-till (chisel plowing), conventional-till (disk plowing to $15 \mathrm{~cm}$ ), and deep-till (disk plowing to $45 \mathrm{~cm}$ ) were used as soil treatments (main plots). Each plot was split into 3 subplots in which watermelon, tomato and pigeon pea were planted. To measure the residual effect, we planted the same crops in the same plots after the first harvest. Combined response of the three test crops to land preparation techniques was not significantly different, nor in general, were individual responses significantly different. Thus, watermelon, tomato and pigeon pea might be grown with minimum- or even no-tillage under the conditions prevailing at the experimental site. No significant differences among treatments were observed with regard to the analyzed plant nutrient levels, pH and soil strength. In the residual effect experiment, watermelon and tomato yields declined considerably, whereas pigeon pea yields increased.
\end{abstract}

\section{INTRODUCTION}

Recent public awareness of pollution problems and the imperative need to reduce labor, fuel and machinery expenditures, as well as to increase net returns and decrease soil erosion, are some of the reasons that have induced farmers to modify their tillage strategies $(3,6,13,14)$. A trend toward conservation tillage has been observed in many countries, including the United States (14). In general, however, the majority of farmers are still reluctant to change production practices, such as conventional till techniques, for fear of, among other things, reduced yields. It is well known that the physical condition of the soil can limit production and that tillage response varies with both crop and soil, as well as with climatic conditions such as rainfall.

Equal or even higher yields have been obtained with minimum or

${ }^{1}$ Manuscript submitted to Editorial Board October 10, 1985.

${ }^{2}$ Agronomists, Agronomy and Soils Department, Agricultural Experiment Station, Mayagüez Campus, University of Puerto Rico.

${ }^{3}$ Assistant Agronomist, Horticulture Department, Agricultural Experiment Station, Mayagüez Campus, University of Puerto Rico. 
no-till as compared with conventional till practices $(3,9,13,15,16)$. In Puerto Rico, Abruña et al. (1), Vicente-Chandler et al. (16), Lugo-Mercado et al. $(11,12)$, and Irizarry et al. (8), working with tanier, tobacco, sugarcane, plantain, yam, corn, peppers, and bean, obtained good yields with no-till techniques. However, some trials by the same researchers have demonstrated that with crops such as tanier, plantain and peppers grown on heavy soils there is possible response to tillage treatments (1, $8,11,12)$.

Inasmuch as land preparation practices depend largely on the physical condition of the soil, as well as on the crop to be grown, it is important to study the effect of tillage practices on each crop and kind of soil under cultivation.

\section{MATERIALS AND METHODS}

Two trials were conducted over a 15-month period (October 1982 through December, 1983) at the Fortuna Research and Development Center in the dry coastal plain of Puerto Rico. Temperatures ranged from 31.7 to $19.5^{\circ} \mathrm{C}$ with an average of $25^{\circ} \mathrm{C}$ in winter and $28^{\circ} \mathrm{C}$ in summer.

\section{First Experiment \\ October 1982-March 1983}

The soil at the experiment site belongs to the San Antón series, (Cumulic Haplustoll, fine-loamy, mixed, isohyperthermic) with a $\mathrm{pH}$ of 7.4 and a CEC of $25 \mathrm{meq} / 100 \mathrm{~g}$ of soil $(7,10)$. Specific data on chemical analysis and particle size distribution for the experimental plots (14 $\mathrm{x} 6$ $\mathrm{m})$ are included as part of table 1 and 2 .

The experimental design followed a split plot arrangemment of a randomized complete block replicated four times, with land preparation methods assigned to main plots; the test crops, watermelon (var. Charleston Gray), tomato (var. Manulucie) and pigeon pea (var. 2B-Bushy) were the subplots $(6 \times 4 \mathrm{~m})$. The land preparation treatments were as follows: 1) no-till (undisturbed); 2) minimum-till (chisel plowing at $30-\mathrm{cm}$ depth); 3) conventional-till (disk plowing at 2 -week interval and $15-\mathrm{cm}$ depth); and 4) deep-till (disk plowing 4 times at a 7-day interval and 45-cm depth).

Pigeon pea and tomato were planted in rows $75 \mathrm{~cm}$ apart at $30 \mathrm{~cm}$ between plants, whereas watermelon was spaced $260 \mathrm{~cm}$ between plants and $150 \mathrm{~cm}$ between rows. All three crops were fertilized at a rate of $1100 \mathrm{~kg} / \mathrm{ha}$ of a $10-10-10$ fertilizer. The experiment was overhead irrigated as needed. Crop management practices such as weed, insect and disease control were as indicated in the technological packages of practices for these crops prepared by the Agricultural Experiment Station of the University of Puerto Rico $(4,5)$. 
A recording penetrometer with a cone area of $0.04 \mathrm{~cm}^{2}$ was used for resistance measurements in each plot at harvesting. A soil sample from each plot was taken for $\mathrm{pH}$, organic matter, chemical analysis $(\mathrm{Ca}, \mathrm{Mg}$, $\mathrm{K}$ and $\mathrm{P}$ ), and particle size distribution as described by Black (2) (tables 1 and 2). Data on stand, yield, as well as chemical and physical analysis, were recorded and statistically analyzed.

\section{Residual Effect Experiment July-December 1983}

After the harvest of the first experiment, a residual effect trial was established July 1983. To measure the residual effect we planted the same crops in the same order and plots of the first experiment without further land preparation other than a two-inch wide furrow for planting. Experimental design, cultural practices, recorded data and statistical analysis were the same as for the first trial.

\section{RESULTS AND DISCUSSION}

Table 3 shows yields of watermelon, tomato and pigeon pea for the first and residual effect trials. No statistically significant variations in watermelon, tomato and pigeon pea yields were found, with the exception of the first pigeon pea and second (residual effect) tomato crops.

TABLE 1.-Average nutrient content, $p H$, and organic matter of the experimental plots

\begin{tabular}{|c|c|c|c|c|c|c|c|}
\hline \multirow[b]{2}{*}{ Treatments } & \multicolumn{5}{|c|}{ Nutrient content } & \multirow[b]{2}{*}{$\mathrm{pH}$} & \multirow[b]{2}{*}{$\mathrm{O} . \mathrm{M}$} \\
\hline & $\overline{p_{1}}$ & $\mathbf{K}$ & $\mathrm{Ca}$ & $\mathrm{Mg}$ & $\mathrm{Na}$ & & \\
\hline & & & $p / m$ & & & & $\%$ \\
\hline No-till & 25 & 394 & 2514 & 498 & 113 & 7.48 & 1.74 \\
\hline Minimum-till & 27 & 373 & 2580 & 505 & 143 & 7.54 & 1.72 \\
\hline Conventional-till & 30 & 358 & 2484 & 496 & 121 & 7.36 & 1.74 \\
\hline \multirow[t]{2}{*}{ Deep-till } & 24 & 386 & 2459 & 499 & 118 & 7.70 & 1.77 \\
\hline & $\mathrm{NS}^{2}$ & NS & $\mathrm{NS}$ & NS & NS & NS & NS \\
\hline
\end{tabular}

IOlsen method.

${ }^{2}$ Not significant at the $5 \%$ probability level.

TABLE 2.-Average particle size distribution and resistance to penetration of the experimental plots

\begin{tabular}{|c|c|c|c|c|}
\hline \multirow[b]{2}{*}{ Treatments } & \multicolumn{3}{|c|}{ Particle size distribution } & \multirow{2}{*}{$\begin{array}{l}\text { Resistance to } \\
\text { penetration }\end{array}$} \\
\hline & Sand & Silt & Clay & \\
\hline & & $\%$ & & $\mathrm{~kg} / \mathrm{cm}^{2^{1}}$ \\
\hline No-till & 38.0 & 35.9 & 26.1 & 9.6 \\
\hline Minimum-till & 41.0 & 32.4 & 26.6 & 9.5 \\
\hline Conventional-till & 40.5 & 32.4 & 27.1 & 7.3 \\
\hline \multirow[t]{2}{*}{ Deep-till } & 40.5 & 33.4 & 26.1 & 7.2 \\
\hline & $\mathrm{NS}^{2}$ & NS & NS & NS \\
\hline
\end{tabular}

${ }^{1}$ Average of 3 determinations per plot at $15 \mathrm{~cm}$ depth.

${ }^{2}$ Not significant at the $5 \%$ probability level. 
TABLE 3.-Watermelon, tomato and pigeon pea yields of the first and residual effect trial as affected by tillage practices

\begin{tabular}{|c|c|c|c|c|c|c|}
\hline \multirow[b]{3}{*}{ Tillage practice } & \multicolumn{6}{|c|}{ Yield (kg/ha) } \\
\hline & \multicolumn{2}{|c|}{ Watermelon } & \multicolumn{2}{|c|}{ Tomato } & \multicolumn{2}{|c|}{ Pigeon pea } \\
\hline & $\begin{array}{l}\text { First } \\
\text { crop }\end{array}$ & Residual & $\begin{array}{l}\text { First } \\
\text { crop }\end{array}$ & Residual & $\begin{array}{l}\text { First } \\
\text { erop }\end{array}$ & Residual \\
\hline No-till & $43,595 \mathrm{a}^{1}$ & $40,032 \mathrm{a}$ & $45,439 \mathrm{a}$ & $13,144 \mathrm{~b}$ & $16,105 \mathrm{~b}$ & $25,062 \mathrm{a}$ \\
\hline Minimum-till & $62,171 \mathrm{a}$ & $37,762 \mathrm{a}$ & $44,288 \mathrm{a}$ & $17,052 \mathrm{a}$ & $16,939 \mathrm{~b}$ & $23.253 \mathrm{a}$ \\
\hline Conventional-till & $68,236 \mathrm{a}$ & $23,925 \mathrm{a}$ & 37,961 a & $19,172 \mathrm{a}$ & $19,498 \mathrm{a}$ & $26,354 \mathrm{a}$ \\
\hline Deep-till & $69,184 \mathrm{a}$ & 33,227 a & $41,988 \mathrm{a}$ & $18,022 \mathrm{a}$ & $17,111 \mathrm{~b}$ & 26,245 a \\
\hline
\end{tabular}

${ }^{1}$ Means (of 4 replicates) followed by the same letter are not statistically different at the $5 \%$ probability level.

The fact that the yield of the first tomato crop was not significant and about twice as high as that of the residual effect trial indicates that the statistically significant differences found were due to factors other than those related to the tillage strategies. That is, under conditions such as those prevailing at the Fortuna Research Center it appears that tomato can be grown without tillage.

Even though no statistically significant differences were found among treatments when watermelon was used as the test crop, the data obtained suggest a possible response to tillage. Perhaps this can be inferred in both trials, since in the first one, yield increased with tillage input; and in the second (residual effect), the yield obtained in the tillage plots approached that of the no-till treatment. The results of the residual effect experiment demonstrated that the suggested beneficial tillage effects on the watermelon plants observed in the first trial faded out by the time the second experiment was established.

The observed pigeon pea yield pattern (table 3) also indicates that this erop may respond to tillage since in both experiments the tilled plots outyielded the no-till and minimum-till plots even though the differences were not significant in the residual effect trial.

The substantial reduction in watermelon and tomato yield observed in the residual effect trial is of particular interest if land like that tested is to be used continuously for the same crop. Because of the short duration of the experiment reported here, we detected no significant differences in the physical and chemical properties of the soil which could explain differences in yield (tables 1 and 2). Nematode population determinations also failed to explain yield drops because the populations found were negligible. In view of the fact that insects were kept under control and water was provided as needed, it appears that a combination of factors such as seasonal effect, nutrient availability as well as an increase in disease attack were responsible for the lower yields of the residual effect experiment. 
Nevertheless, the results confirm observations of previous work with crops, such as corn, bean and peppers (12), that watermelon, tomato and pigeon pea can be grown in soils similar to San Antón with minimum-till and even with no-till, especially if cultural practices such as fertilization and disease control are improved.

\section{RESUMEN}

\section{Rendimientos de sandía, tomate y gandul en terrenos preparados según distintas técnicas}

Se evaluaron tres técnicas diferentes para preparar el terreno para sandías, tomate y gandul en un suelo de la serie San Antón (del orden de los Mollisol) en la región sur de Puerto Rico. Las diferentes formas de preparar el suelo se compararon con la técnica de sembrar sin labranza. Los tratamientos fueron: 1) sin labranza; 2) labranza mínima (remover el suelo sin voltearlo), 3) labranza convencional (dos cortes de arado a una profundidad de $15 \mathrm{~cm}$ cada 2 semanas); 4) labranza profunda (4 cortes de arado a una profundidad de $45 \mathrm{~cm}$ cada semana). Cada parcela tratada se dividió en tres, en las que se sembraron los cultivos indicados. Después de cosechar el primer experimento se sembraron otra vez las mismas cosechas en los mismos sitios para medir el efecto residual. No se observaron respuestas estadísticamente significativas de los tratamientos en los cultivos estudiados. En general, la respuesta individual tampoco fue significativa. Los resultados obtenidos sugieren la posibilidad de que estos cultivos puedan sembrarse con labranza mínima y en algunos casos hasta sin labraza, si se establecen en condiciones similares a las que prevalecieron en el estudio que aquí se informa. No se detectaron diferencias significativas entre tratamientos con respecto a resistencia a la penetración, $\mathrm{pH}$ y concentración de $\mathrm{N}, \mathrm{P}, \mathrm{K}, \mathrm{Ca}, \mathrm{Mg}$. Se registró una reducción substancial an el rendimiento de sandía y tomate cuando el mismo cultivo se sembró en el mismo lugar dos veces consecutivas.

\section{LITERATURE CITED}

1. Abruña, F., E. G. Boneta, J. Vicente-Chandler and S. Silva, 1967. Experiments on tanier production with conservation in Puerto Rico's mountain region. J. Agric. Univ. P. R. 51: 167-75.

2. Black, C. A., Ed, 1965. Methods of Soil Analysis. Part 1 and 2. Agronomy 9: 552-476. Am. Soc. Agron., Madison, Wis.

3. Blevins, R. L., 1970. No tillage suitability to Kentucky soil. In Phillips, R., Thomas, G. and Blevins, R., Eds, No-tillage research: Research Reports and Reviews. University of Kentucky.

4. Conjunto Tecnológico para la Producción de Hortalizas, 1976. Esta. Exp. Agríc. Univ. P. R. Publ. 102.

5. Conjunto Tecnológico para la Producción de Gandules; su Situación Económica y Perspectivas, 1977. Esta. Exp. Agríc. Univ. P. R. Publ. 116.

6. Frye W., J. Walker and G. Duncan, 1979. Comparison of energy requirements of no tillage and conventional tillage. In Phillips, R., Thomas, G., and Blevins, R. Eds, No Tillage Research: Res. Rep. and Rev. University of Kentucky. pp. 76-83.

7. Gierbolini, R. E., 1979. Soil Survey of the Ponce Area of Southem Puerto Rico, USDA, Soil Conservation Service. 
8. Irizarry, H., E. Rivera, J. A. Rodríguez and J. J. Green, 1978. Effect of planting pattern and population density on yield and quality of horn-type Maricongo plantain (Musa acuminata $\times M$. balbisiana, AAB) in North Central Puerto Ricol. J. Agric. Univ. P. R. 62: 214-23.

9. Lal, R., 1979. No-tillage farming in the tropics. In Phillips, R., C. Thomas and R. Blevins, Eds. No tillage Research: Research Reports and Review. Univ. of Kentucky, pp. 103-51.

10. Lugo-López, M. A. and L. H. Rivera, 1977. Updated taxonomic classification of the soils of Puerto Rico, Univ. P. R. Agric. Exp. Stn. Univ. P. R. Bull. 258.

11. Lugo-Mercado, H. M., J. Badillo-Feliciano and J. López-García, 1978. Effects of Soil Compaction on Tanier Yields. J. Agric. Univ. P. R. 62: 56-63.

12. - and F. H. Ortiz-Alvarado, 1984. Comparison of no-tillage versus various tillage methods on maize, field beans and peppers yield grown on a Mollisol of southern Puerto Rico, J. Agric. Univ. P. R. 68 (4): 349-54.

13. Mosehler, W., G. Shear, D. Martens, G. Jones and R. Willmowth, 1972. Comparative yield and fertilizer efficiency of no-tillage and conventionally tillage corn., Agric. J. 64 (2): 229-31.

14. Successful Farming, 1982. Conservation Tillage Guide. Dick Hanson, Ed, Ciga-Geigi Corporation, Greensboro, N. C.

15. Triplett, G. and D. Van Daren, 1969. Nitrogen, phosphorus and potassium fertilization on non-tilled maize, Agron. J. 61 (4): 636-39.

16. Vicente-Chandler, J., R. Costas and E. Boneta, 1966. High crop yield produced with or without tillage on three typical soils of the humid region of Puerto Rico, J. Agric. Univ. P. R. 50 (2): 146-50. 